\title{
ANALISIS KESALAHAN SISWA KELAS VI SDN 2 TAMANSARI TAHUN PELAJARAN 2015/2016 DALAM MENYELESAIKAN SOAL MATEMATIKA UASBN 2014/2015
}

\author{
Yuni Mariyati ${ }^{1}$, Riyadi $^{2}$, Musfiatul Wardi $^{3}$ \\ $1_{\text {Dosen PGSD UMmat, }} 2_{\text {Dosen UMMAT, }}{ }^{\text {Dosen UMMAT }}$ \\ yunimariyati31@gmail.com
}

\begin{tabular}{l} 
INFO ARTIKEL \\
\hline Riwayat Artikel: \\
Diterima: $05-12-2017$ \\
Disetujui: $26-12-2017$
\end{tabular}

Kata Kunci:

1. Analisis kesalahan siswa,

2. Soal UASBN SD/MI

\begin{abstract}
ABSTRAK
Abstrak: Penelitian ini bertujuan untuk: (1) mengidentifikasi jenis kesalahan siswa kelas VI SDN 2 Tamansari dalam menyelesaikan soal-soal matematika UASBN tahun pelajaran 2014/2015 (2) untuk mendeskripsikan sumber kesalahan siswa kelas VI SDN 2 Tamansari dalam menyelesaikan soal-soal matematika UASBN tahun pelajaran 2014/2015. Penelitian merupakan penelitian deskriptif. Subyek penelitian adalah siswa kleas VI SDN 2 Tamansari yang berjumlah 32 siswa. Pengumpulan data dilakukan dengan menggunakan tes dan wawancara terhadap subjek untuk memperjelas jenis dan sumber kesalahan siswa. Analisis data dilakukan dengan menghitung jumlah kesalahan siswa, menganalisis hasil tes dan wawancara, dan menarik kesimpulan. Hasil dari penelitian ini menunjukkan bahwa: (1) jenis kesalahan siswa SDN 2 Tamansari dalam menyelesaikan soal-soal matematika UASBN tahun pelajaran 2014/2015 meliputi: kesalahan fakta, kesalahan pemahaman soal, kesalahan konsep, kesalahan transformasi, kesalahan prinsip, kesalahan melakukan operasi, kesalahan menentukan kedudukan benda. (2) sumber kesalahan siswa meliputi: kurang menguasai operasi hitung bilangan dan sifat-sifat operasi hitung, kurang memahami makna soal, kurang menguasai rumus yang tepat untuk menyelesaikan soal, kurang menguasai operasi pecahan, mengurutkan pecahan, kurang menguasai skala dan perbandingan, kurang menguasai KPK dan FPB dan penggunaannya dalam menyelesaikan masalah, kurang menguasai pengukuran, kurang menguasai geometri, kurang menguasai sifat pencerminan bidang datar, kurang menguasai cara menafsirkan titik pada bidang cartesius, kurang menguasai cara membaca data dan kurang latihan soal
\end{abstract}

\section{A. LATAR BELAKANG}

Pemerintah berupaya untuk meningkatkan mutu pendidikan dengan berbagai hal, yang salah satunya adalah dengan mengadakan Ujian Nasional. Ujian Nasional merupakan sebuah penentu keberhasilan bagi seorang peserta didik dalam belajar di suatu sekolah. Selanjutnya dalam Permendiknas No 82 tahun 2008 menjelaskan Ujian Nasional (UN) adalah salah satu implementasi pelaksanaan penilaian oleh pemerintah dengan tujuan untuk menilai pencapaian kompetensi lulusan secara nasional pada mata pelajaran Bahasa Indonesia, Matematika, dan Ilmu Pengetahuan Alam (IPA); dan mendorong tercapainya target wajib belajar pendidikan dasar yang bermutu.

Pemerintah menggunakan UASBN sebagai instrumen pengukuran dan penilaian kompetensi peserta didik secara nasional. Hal ini sejalan dengan Peraturan Menteri pendidikan Nasional Republik Indonesia Nomor 45 tahun 2006 pasal 1 yang menegaskan bahwa Ujian Nasional adalah kegiatan pengukuran dan penilaian kompetensi peserta didik secara nasional untuk jenis pendidikan dasar dan menengah.

Permendiknas No 82 tahun 2008 menyebutkan bahwa Soal-soal ujian yang diberikan pada UASBN menggunakan standar kompetensi kelulusan irisan (interseksi) dari pokok bahasan kurikulum 1994, standar kompetensi dan kompetensi dasar pada kurikulum 2004, dan standar isi 2006. Mata pelpelajaran yang diujikan dalam pada UASBN untuk SD, MI, dan SDLB meliputi matematika, bahasa Indonesia, dan ilmu pengetahuan alam (IPA). Dari ketiga mata pelpelajaran yang diujikan, matematika dianggap sebagai mata pelpelajaran yang menakutkan. Fenomena yang terjadi dimasyarakat menyebutkan bahwa siswa 
Jurnal Elementary | Vol. 1, No. 1, Januari 2018, hal 26-30

kesulitan dalam menyelesaikan soal matematika khususnya soal UASBN.

Kesulitan siswa dalam menyelesaikan soal matematika, terlihat dari penelitian dari hasil penelitian Drs. H. Sumardi, M.Si terhadap analisis jawaban hasil UASBN dari seluruh SD di kabupaten Sukoharjo tahun 2009 yang dilakukan terhadap 12 kecamatan, 462 sekolah dasar dengan 9779 siswa diperoleh hasil siswa SD mengalami kesulitan dalam materi aritmatika, pengukuran dan geometri, serta pengolahan data.

Selanjutnya dari hasil observasi wawancara terhadap guru SDN 2 Tamansari pada tanggal 5 april 2016, siswa sering melakukan kesalahan dalam menyelesaikan soalsoal UASBN, salah satunya adalah kesalahan dalam perhitungan. Selain itu, banyak juga siswa yang masih salah dalam memasukkan rumus. Hal ini dapat disebabkan karena siswa lebih cenderung hanya menghafalkan rumus, kurang memahami konsep secara benar.

Selain kesalahan-kesalahan tersebut, tidak tertutup kemungkinan masih terdapat kesalahan-kesalahan lain yang dilakukan oleh siswa. Untuk itulah perlu adanya usaha-usaha untuk mengurangi kesalahan-kesalahan yang ada. Peranan guru dalam memberikan konsep-konsep matematika sangat menentukan keberhasilan anak dalam memahami konsep matematika pada tingkat yang lebih tinggi. Guru harus berani merubah konsep yang salah dan terlanjur diajarkan kepada siswa sehingga pemahaman konsep yang salah tidak berlarut-larut, yang berakibat fatal bagi anak dalam memahami konsep pada tingkat yang lebih tinggi khususnya tentang bagaimana menyelesaikan soal UASBN.

Berdasarkan latar belakang tersebut, penulis berusaha untuk mengidentifikasi jenis dan sumber kesalahan yang dilakukan oleh siswa kelas VI SDN 2 Tamansari dalam mengerjakan soal UASBN Tahun pelajaran 2014/2015, sehingga prestasi belajar matematika dapat ditingkatkan.

\section{B. METODE PENELITIAN}

Penelitian ini adalah kualitatif, pendekatan penelitian yang digunakan dalam penelitian ini adalah menekankan pada karakter penelitian deskriptif. Dimana dalam penelitian ini data yang dikumpulkan adalah berupa katakata, gambar, dan bukan berupa angka-angka (Moleong, 2009 : 11). Penelitian ini dilaksanakan di SDN 2 Tamansari yang berlokasi di dusun Gunungsari desa Tamansari kecamatan Gunungsari. Waktu penelitian dilaksanakan pada tanggal $6-7$ april 2016 semester genap tahun pelajaran 2015/2016. Adapun yang menjadi Subyek penelitian ini adalah siswa kelas VI SDN 2 Tamansari sebanyak 32 orang siswa yang terdiri dari 15 orang berjenis kelamin perempuan dan 13 orang berjenis kelamin laki-laki.

Metode pengumpulan data yang digunakan adalah metode tes dan wawancara. Data dalam penelitian ini adalah jenis kesalahan yang dilakukan oleh siswa kelas VI SDN 2 Tamansari Tahun pelajaran 2015/2016 dalam mengerjakan soal matematika UASBN Tahun pelajaran 2014/2015. Sumber data yang di gunakan dalam penelitian ini adalah soal UASBN matematika SD/MI tahun pelajaran 2014/2015. Selanjutnya Soal pada UASBN matematika SD/MI tahun pelajaran 2014/2015 yang terkumpul akan di analisis untuk menggambarkan kesalahan siswa. Analisis data dilakukan dengan menganalisis hasil tes berdasar jenis kesalahan setiap item soal.

\section{HASIL DAN PEMBAHASAN}

Materi ajar yang terdapat dalam tiap-tiap kode soal terdiri dari materi bilangan yang meliputi sifat-sifat operasi hitung bilangan serta penggunaanya dalam pemecahan masalah; materi pengukuran yang meliputi penggunaan satuan-satuan panjang, berat dan waktu; materi geometri meliputi unsur-unsur yang terdapat dalam bangun datar dan bangun ruang serta penggunaan bidang koordinat cartesius; materi pengolahan data yang meliputi penyajian data dalam bentuk tabel dan diagram, menentukan ratarata, modus, dan menentukan median dari suatu data.

Dari 40 soal pilihan ganda pada Ujian Akhir Sekolah Berstandar Nasional (UASBN) matematika kelas VI SD/MI Tahun pelajaran 2014/2015 dapat diketahui materi ajar Geometri dan Pengukuran merupakan materi ajar yang banyak digunakan dalam soal tersebut yaitu sebesar 17 soal, kemudian materi ajar Aritmatika memiliki jumlah 13 soal, Sedangkan materi pengolahan data memiliki jumlah paling sedikit yaitu 10 soal.

Dalam penelitian ini, peneliti menganalisis mengenai jenis kesalahan siswa pada saat mengerjakan soal UASBN matematika SD/MI Tahun Pelajaran 2014/2015 yang dihubungkan dengan objek dasar matematika menurut Soedjadi (2000: 13), sehingga jenis kesalahan yang dimaksud yaitu: kesalahan fakta, kesalahan pemahaman soal, kesalahan konsep, kesalahan transformasi, kesalahan prinsip, dan kesalahan melakukan operasi. Selanjutnya, peneliti menganalisis sumber kesalahan siswa dalam mengerjakan soal UASBN matematika Tahun Pelajaran 2014/2015 yang diperoleh pada hari rabu 6 April 2016.

Berikut penjabaran hasil peneliti menganalisis jenis dan sumber kesalahan siswa dalam mengerjakan soal UASBN matematika Tahun Pelajaran 2014/2015; Kesalahan pertama adalah jenis kesalahan fakta, berikut tabel penjabaran kesalahan fakta dan sumber kesalahan siswa dalam menyelesaikan soal matematika UASBN SD/MI.

Tabel 4.1. Deskripsi jenis kesalahan fakta

\begin{tabular}{ll} 
Sumber Kesalahan & No soal \\
\hline salah dalam menginterpretasikan hasil & $8,9,10,11$ \\
yang didapatkan atau menarik & \\
kesimpulan &
\end{tabular}

Dari tabel di atas dijabarkan Jenis dan sumber kesalahan siswa yaitu; jenis kesalahan fakta, dimana siswa salah dalam mengambil kesimpulan KPK untuk soal nomor 
8 dan 10 dan FPB pada nomor 9 dan 11. Salah satu contoh, siswa menentukan KPK dari 6 dan 8 adalah 2, dimana 2 adalah FPB dari 6 dan 8, seharusnya jawaban siswa adalah $2 \times 2 \times 2 \times 3=24$ untuk KPK.

Selanjutnya siswa mengalami jenis kesalahan pemahaman soal, seperti tidak menuliskan diketahui dan ditanyakan, serta salah dalam menuliskan diketahui dan ditanyakan pada soal cerita dari materi aritmatika, pengukuran dan geometri, sehingga siswa salah mengambil startegi. Berikut tabel penjabaran kesalahan pemahaman soal dan sumber kesalahan siswa;

Tabel 4.2. Deskripsi jenis kesalahan pemahaman soal

\begin{tabular}{lll} 
Sumber kesalahan & & No soal \\
\hline Tidak menuliskan & diketahui & $2,4,6,8,10,11,14,15$, \\
dan ditanyakan & & $16,17,18$ \\
salah menuliskan & diketahui & $27,28,29$ \\
dan ditanyakan & & \\
\hline
\end{tabular}

Pada tabel di atas kesalahan siswa yang tidak bisa menuliskan diketahui dan ditanyakan atau mengosongkan jawaban yaitu pada soal no 4, 6, 8, 10,11, 14, 15, 16, 17, dan 18. Salah satu contoh siswa tidak memahami soal cerita, terlihat pada soal nomor 27, seharusnya penyelesaiannya adalah $(60 \times 50 \times 35): 2=52.500$, tetapi siswa melakukan kesalahan berikut $(60 \times 50 \times 35)=105.000$, selanjutnya kesalahan juga terlihat pada soal no 28 dan 29 yaitu siswa salah dalam menentukan alas dan tinggi. kesalahan siswa terjadi karena siwa kurang melakukan latihan-latihan soal dalam konteks nyata.

Selanjutnya siswa melakukan kesalahan konsep, berikut tabel penjabaran kesalahan konsep dan sumber kesalahan siswa;

\section{Tabel 4.3. Deskripsi jenis kesalahan konsep}

\begin{tabular}{ll}
\hline Sumber kesalahan & $\begin{array}{l}\text { No } \\
\text { soal }\end{array}$ \\
\hline $\begin{array}{l}\text { Salah mengartikan tanda pada saat } \\
\text { mengurutkan pecahan, }\end{array}$ & 7 \\
$\begin{array}{l}\text { salah mengartikan bilangan berpangkat } \\
\text { Tidak memahami sifat pencerminan bidang }\end{array}$ & 12 \\
$\begin{array}{l}\text { datar } \\
\text { Salah membedakan rusuk dan tinggi, }\end{array}$ & 21 \\
$\begin{array}{l}\text { Tidak memahami sifat-sifat kesebangunan } \\
\text { bangun datar, }\end{array}$ & 22 \\
$\begin{array}{l}\text { Tidak memahami sifat jaring-jaring bangun } \\
\text { ruang }\end{array}$ & 23 \\
Tidak memahami arti selisih & 40 \\
\hline
\end{tabular}

Dari tabel di atas dapat dijabarkan beberapa kesalahan siswa yaitu; siswa kurang mampu mengartikan tanda pada saat mengurutkan pecahan, siswa salah mengartikan 0,25 > 0,5, kesalahan selanjutnya siswa salah mengartikan bilangan berpangkat yaitu siswa menjumlahkan bukan mengalikan yaitu $19^{2}=19+19$. Siswa tidak bisa membedakan rusuk dan tinggi pada bangun limas segi empat, sehingga siswa menjawab bahwa jumlah rusuk pada limas segi empat adalah 11, selanjutnya siswa juga kurang memahami sifat-sifat kesebangunan bangun datar sehingga siswa salah dalam memilih dua buah bangun datar yang sebangun, kesalahan juga terjadi pada soal pencerminan bidang datar dan jaring-jaring bangun ruang dimana siswa tidak memahami sifat-sifat pencerminan maupun sifat-sifat jaring-jaring pada bangun ruang balok dan tidak bisa mengartikan selisih sebagai beda atau hasil pengurangan bilangan tertinggi dan bilangan terendah.

Selanjutnya, kesalahan siswa dalam menjawab soal matematika UASBN adalah kesalahan transformasi, berikut tabel penjabaran kesalahan transformasi dan sumber kesalahan siswa;

Tabel 4.4. Deskripsi jenis kesalahan transformasi

\begin{tabular}{ll} 
Sumber kesalahan & No Soal \\
\hline $\begin{array}{l}\text { Salah menafsirkan letak titik pada bidang } \\
\text { cartesius, }\end{array}$ & 30 \\
$\begin{array}{l}\text { Salah menafsirkan diagram batang } \\
\text { Salah mengubah tabel menjadi diagram } \\
\text { batang, }\end{array}$ & 31 \\
\hline
\end{tabular}

Pada tabel di atas kesalahan transformasi terlihat pada saat siswa menafsirkan membaca dan menafsirkan letak titik pada bidang cartesius misalnya siswa salah dalam menafsirkan letak titik $\mathrm{R}$ pada bidang cartesius, dimana siswa menuliskan terlebih dahulu -2 pada sumbu $Y$ baru menuliskan 3 pada sumbu $X$, sehingga menyimpulkan titik $\mathrm{R}$ berada di garis penghubung $(-2,3)$ seharusnya siswa menjawab titik $R$ berada pada garis $(3,-2)$, dimana nilai sumbu $X$ terlebih dahulu ditulis daripada nilai pada sumbu Y.Selanjutnya siswa salah menafsirkan atau mengubah data pada tabel menjadi gambar diagram batang, dan siswa salah membaca data pada diagram batang.

Selanjutnya adalah kesalahan prinsip, dimana siswa salah dalam mengambil strategi atau menggunakan rumus dalam menjawab soal matematika UASBN SD/MI, berikut tabel penjabaran kesalahan prinsip dan sumber kesalahan siswa;

Tabel 4.5. Deskripsi jenis kesalahan prinsip

Sumber kesalahan No soal




\begin{tabular}{ll} 
Salah rumus perbandingan & 6 \\
salah rumus dalam menyelesaikan KPK & 8,9, \\
$\begin{array}{l}\text { salah rumus dalam menyelesaikan soal FPB, } \\
\text { Salah rumus penarikan akar dan }\end{array}$ & 13,11 \\
$\begin{array}{l}\text { penggunaan dalam menyelesaikan masalah } \\
\text { salah rumus dalam pengukuran panjang }\end{array}$ & 15,17 \\
$\begin{array}{l}\text { dan berat } \\
\text { salah rumus debit }\end{array}$ & 16 \\
$\begin{array}{l}\text { salah rumus pada saat mencari kecepatan, } \\
\text { salah rumus pada saat mencari luas bangun }\end{array}$ & 18 \\
$\begin{array}{l}\text { datar, } \\
\text { salah rumus bangun ruang, }\end{array}$ & $27,28,29$ \\
$\begin{array}{l}\text { salah rumus dalam menafsirkan data pada } \\
\text { diagram lingkaran, }\end{array}$ & 32 \\
salah rumus mencari rata-rata, & $35,36,37$ \\
salah rumus modus & 38 \\
salah rumus median & 39 \\
\hline
\end{tabular}

Pada tabel di atas dijabarkan kesalahan siswa dalam menyelesaikan soal matematika UASBN adalah siswa melakukan kesalahan prinsip, dimana siswa salah menggunakan rumus dalam menyelesaikan soal perbandingan, rumus KPK untuk meyelesaikan soal FPB dan rumus FPB untuk menyelesaikan soal KPK, selain itu siswa juga menggunakan kelipatan untuk menyelesaikan KPK padahal yang diminta adalah dengan menggunakan faktorisasi prima, selanjutnya siswa salah rumus pada saat mencari kecepatan, salah rumus pada saat mencari luas bangun datar dan bangun ruang, salah satu contoh, siswa menggunakan rumus jajar genjang yaitu a $\mathrm{x} t$ sehingga menghasilkan 250, seharusnya rumus yang digunakan pada bangun datar trapesium tersebut adalah jumlah dua sisi yang sejajar dikalikan tinggi kemudian hasilnya di bagi 2 , jadi diperoleh $\frac{(15+25) \times 10}{2}=200 \mathrm{~cm}^{2}$. Selanjutnya, siswa salah dalam menafsirkan data pada diagram lingkaran, salah rumus dalam mencari rata-rata, modus dan median pada soal pengolahan data.

Selanjutnya adalah kesalahan operasi hitung dalam penjumlahan, pengurangan, perkalian dan pembagian dalam menjawab soal matematika UASBN SD/MI, berikut tabel penjabaran kesalahan operasi hitung dan sumber kesalahan siswa;

\section{Tabel 4.6. Deskripsi jenis kesalahan operasi hitung}

\begin{tabular}{ll}
\hline Sumber kesalahan & No soal \\
\hline $\begin{array}{l}\text { kesalahan operasi hitung bilangan bulat } \\
\text { pada pengurangan, penjumlahan, }\end{array}$ & \\
perkalian dan pembagian & \\
salah dalam melakukan operasi hitung & 4,5 \\
penjumlahan, perkalian dan pembagian & \\
bilangan pecahan &
\end{tabular}

Kesalahan siwa melakukan operasi hitung, terlihat dari kesalahan siswa pada saat mengerjakan operasi hitung pengurangan, penjumlahan, perkalian dan pembagian, dimana siswa melakukan operasi hitung pengurangan dan penjumlahan terlebih dahulu. Salah satu kesalahan siswa dalam melakukan operasi hitung pada saat mengerjakan soal UASBN 2014/2015 adalah siswa mengerjakan pengurangan terlebih dahulu daripada pembagian, seharusnya siswa mengerjakan terlebih dahulu pembagian atau perkalian dari pada pengurangan, berikut penjabarannya; $120-42: 6 \times 3=120-7 \times 3=120-21=99$. Selain itu, siswa salah dalam melakukan penjumlahan dan perkalian bilangan pecahan, terlihat dari kesalahan siswa dalam menempatkan nilai tempat pada saat melakukan operasi hitung pecahan desimal.

Selain penjabaran tentang jenis dan sumber di atas, terlihat kesulitan siswa dalam mengerjakan soal UASBN yaitu siswa lebih banyak memberikan jawaban salah tanpa disertai dengan langkah-langkah penyelesaian yang benar dan sistematis, selain itu ada beberapa siswa yang memilih jawaban bena tetapi tidak mencantumkan cara penyelesaian. Selanjutnya, ada beberapa siswa tidak memberikan pilihan jawaban. Untuk menganalisis dan memperjelas kesalahan siswa tersebut, peneliti melakukan wawancara pada hari rabu tanggal 6 April 2016 wawancara dilakukan terhadap 3 orang siswa yang memiliki kesalahan terbanyak pada item jenis kesalahan yang paling banyak, sehingga di peroleh kesimpulan bahwa, penyebab siswa tidak mencantumkan cara penyelesaian, tidak memilih pilihan jawaban dan tidak memberikan penyelesaian yang benar adalah karena siswa tidak memahami soal dan lupa langkah-langkah atau rumus untuk menyelesaikan soal. Selain itu, siswa juga kurang melakukan latihan-latihan soal UASBN.

\section{SIMPULAN DAN SARAN}

Berdasarkan hasil penelitian dan pembahasan disimpulkan bahwa; (1) jenis kesalahan siswa SDN 2 Tamansari dalam menyelesaikan soal-soal matematika UASBN tahun pelajaran 2014/2015 meliputi: kesalahan fakta, kesalahan pemahaman soal, kesalahan konsep, kesalahan transformasi, kesalahan prinsip, kesalahan melakukan operasi, kesalahan menentukan kedudukan benda, dan kesalahan karena kecerobohan. (2) sumber kesalahan siswa meliputi: kurang menguasai operasi hitung bilangan dan sifat-sifat operasi hitung, kurang memahami makna soal, kurang menguasai rumus yang tepat untuk menyelesaikan soal, kurang menguasai operasi pecahan, kurang menguasai skala dan perbandingan, kurang menguasai perpangkatan dan penarikan akar, kurang menguasai KPK dan FPB dan penggunaannya dalam menyelesaikan masalah, kurang menguasai pengukuran, kurang menguasai geometri, kurang menguasai sifat pencerminan bidang datar, kurang menguasai cara menafsirkan titik pada bidang cartesius, kurang menguasai cara membaca data dan kurang latihan soal. 
Berdasarkan hasil penelitian yang diperoleh peneliti memberikan saran sebagai berikut; (1) Untuk siswa agar belajar latihan soal dan lebih meningkatkan kemampuan pemahamannya agar tidak melakukan kesalahan matematika. (2) Untuk guru sebaiknya melakukan pemilihan metode yang tepat untuk siswa dalam memahamkan fakta, konsep, prosedur, prinsip, memahami soal, transformasi dan operasi hitung, sehingga siswa mampu menerapkan dalam menyelesaikan soal-soal. Selain itu, pemberian latihan terus-menerus pada siswa menjadi salah satu cara untuk memperbaiki kesalahan-kesalahan siswa dalam menjawab soal. (3) soal tes UASBN yang diteliti sebaiknya belum pernah dilakukan pengayaan sebelumnya, sebaiknya jangan dibahas terlebih dahulu sebelum peneliti melakukan wawancara. Karena peneliti tidak akan memperoleh informasi yang lebih dalam atau mengorek lebih jauh kesalahan yang dilakukan siswa. Karena siswa sudah mengetahui jawaban terlebih dahulu.

\section{DAFTAR RUJUKAN}

[1] Moleong, Lexy J. 2009. Metodologi Penelitian Kualitatif: EdisiRevisi. Bandung:PT Remaja Rosdakarya.

[2] Soedjadi, R. 2000. Kiat Pendidikan Matematika di Indonesia . Jakarta : Direktoratjenderal Pendidikan Tinggi Dpartemen Pendidikan Nasional.

[3] Peraturan Menteri Pendidikan Nasional Nomor 82 tahun 2008 tentang Ujian Akhir Sekolah Berstandar Nasional (UASBN)untuk Sekolah Dasar /Madrasah Ibtidaiyah/Sekolah Dasar Luar Biasa (SD/MI/SDLB) tahun pelajaran 2008/2009 